\title{
EFFECTS OF CHEMICAL FERTILIZER, FYM AND BIO-INOCULANTS ON NUTRIENT CONTENT, UPTAKE AND QUALITY OF WHEAT (TRITICUM AESTIVUM L.)
}

\author{
Hanuman Prasad Parewa ${ }^{1 *}$, J Yadav, VS Meena ${ }^{2 *}$ and A Rakshit \\ Department of Soil Science and Agricultural Chemistry, Institute of Agricultural Sciences, \\ BHU, Varanasi 221005 Uttar Pradesh, India
}

Keywords: Fertilizer, FYM, Bio-inoculants, Nutrient uptake, Quality

\begin{abstract}
Effects of different levels of chemical fertilizer, farmyard manure (FYM) and bio-inoculants on nutrient content, uptake and quality parameter of wheat were studied. Results indicated that increasing levels of chemical fertilizer, FYM and bio-inoculants significantly enhanced nutrient content and uptake by wheat, while quality parameters of wheat showed significant results with bio-inoculants application. Maximum N, P and $\mathrm{K}$ content and their uptake in grain $(80.3,11.07$ and $25.29 \%$, respectively) and straw $(32.18,7.14$ and 95.92\%, respectively) were noticed with 100\% NPK over control. Application of FYM @ 10 t/ha significantly increased nutrient content (NPK) in grain and straw and their uptake over the control. The total $\mathrm{N}, \mathrm{P}$ and $\mathrm{K}$ uptake by wheat were found to be maximum $80.97,12.68$ and $86.10 \mathrm{~kg} / \mathrm{ha}$, respectively with the application of FYM over control. Combined use of fertilizer levels and FYM, and combined use of fertilizer levels and bio-inoculants significantly increased the nutrient uptake by wheat.
\end{abstract}

\section{Introduction}

India being the second largest producer of wheat (Triticum aestivum L.) $99.70 \mathrm{Mt}$ cover the largest area under its cultivation (29.58 Mha), which is about $14 \%$ of the world wheat area and average productivity of $3377 \mathrm{~kg} / \mathrm{ha}$ (MoA and FW 2018) were recorded. Poor soil fertility and multi nutrient deficiencies in Indian soil are the major constraints to sustain production and productivity. Nutrient mining by intensive cropping systems and inadequate supply of nutrients have aggravated the situation as well as imbalance and excessive fertilizer application is major one. Changes in physico-chemical composition of the soil greatly affected its yield and quality. Injudicious application of chemical fertilizers not only harms the biological power of soil but also decreases the soil fertility and crop productivity (Chand 2008, Parewa et al. 2014). Declining soil fertility has also raised concerns about the sustainability of agricultural production at current levels. Consequently, strategies for increasing and sustaining agricultural productivity will have to focus on using available nutrient resources more efficiently, effectively, and sustainably than in the past. It is recognized that neither organic manure nor chemical fertilizers alone can achieve yield sustainability under modern farming where nutrient depletion and turnover in soil plant systems are quite high. This has in turn paved the way for integrated plant nutrient management. Thus, integrated nutrient management advocates balanced and conjoint use of inorganic fertilizer, organic manure, and bio-inoculants in order to maintenance or adjustment of soil fertility and plant nutrient supply to an optimum level for sustaining desired crop productivity (Rakshit et al. 2008, Parewa et al. 2014). The present study was undertaken to study the role of inorganic fertilizers, FYM and bio-inoculants and their interaction effect on the nutrient content, uptake and quality parameter of wheat crop.

*Author for correspondence: <haniparewa@gmail.com>, <v.meena@cgiar.org>. ${ }^{1}$ College of Agriculture, (Agriculture University, Jodhpur) Sumerpur, Pali 306902 Rajasthan, India. ${ }^{2}$ Borlaug Institute for South Asia (BISA), CIMMYT, Pusa, Samastipur, Bihar, 848125, India. 


\section{Materials and Methods}

The field experiments were conducted during the rabi seasons of 2009-10 and 2010-11 at Agricultural Research Farm, Institute of Agricultural Sciences, BHU, Varanasi $\left(25^{\circ} .18^{\prime} \mathrm{N}\right.$ latitude, $83^{\circ} .30^{\prime} \mathrm{E}$ longitude, $\left.128.93 \mathrm{amsl}\right)$, Uttar Pradesh, India. The experimental site lies approximately in the centre of North-Gangetic alluvial plain. The experimental site was homogeneously fertile with uniform textural make-up. The experiments were laid out on sandy loam soil which was low in organic carbon and available nitrogen, medium in available $\mathrm{P}$ and high fertility status of $\mathrm{K}$. The experiment consisted of 32 treatment combinations of four levels of chemical fertilizer $(0,50,75$ and $100 \%$ NPK) which were assigned in main plots, two level of FYM $(0,10$ t/ha) in sub-plot and four consortia levels i.e. No inoculation, composite consortia (Azotobacter chroococcum W5 + Azospirillum brasilence $\mathrm{Cd}+$ Bacillus megaterium BHUPSB14 + Pseudomonas fluorescens BHUPSB06), VAM and composite consortia + VAM (Glomus fasciculatum) inoculation in subsub plots with three replications. A uniform dose of nitrogen, phosphorus and potash at the rate of $120 \mathrm{~kg}, 60 \mathrm{~kg}$ and $60 \mathrm{~kg} / \mathrm{ha}$ was applied through urea $(46 \% \mathrm{~N})$, di-ammonium phosphate $(18.1 \% \mathrm{~N}$ and $\left.46 \% \mathrm{P}_{2} \mathrm{O}_{5}\right)$ and muriate of potash $\left(60 \% \mathrm{~K}_{2} \mathrm{O}\right)$, respectively. The half dose of nitrogen and full dose of phosphorus and potash were applied as basal dressing at the time of sowing and remaining half dose of nitrogen was applied in equal portion as top dressing after first and second irrigation. The whole dose of FYM @ 10 t/ha was applied 20 days before sowing as per treatment. The wheat variety HUW -234 was sown on 11 and 8 December in the year of 2009-10 and 2010-11, respectively using $100 \mathrm{~kg}$ seed/ha. Bio-inoculants were applied at the time of sowing by treating the seeds with consortia (Azotobacter chroococcum W5 + Azospirillum brasilence $\mathrm{Cd}+$ Bacillus megaterium BHUPSB14 + Pseudomonas fluorescens BHUPSB06) a few hours before sowing. Mycorrhiza were mixed with soil and poured in open furrow before sowing the wheat seed as per the treatment. Appropriate management practices were adopted to raise the crop. Nutrient content in wheat was determined by the standard methods (Jackson 1973, Singh et al. 2005). Nutrient (N, $\mathrm{P}$ and $\mathrm{K}$ ) uptake ( $\mathrm{kg} / \mathrm{ha}$ ) were estimated by standard formula. Protein and total Carbohydrate in wheat were determined by the colorimetric and Anthrone method (Lowry et al. 1951) and Thimmaiah (1999), respectively. Results were analysed using standard statistical procedure given by Gomez and Gomez (1984).

\section{Results and Discussion}

Results presented in Tables 1 and 2 revealed that application of each fertilizer levels significantly enhanced $\mathrm{N}, \mathrm{P}$ and $\mathrm{K}$ content, uptake in grain and straw of wheat and quality parameter and yield of wheat. Data showed that maximum N, P, and K content in grain $(1.60,1.60$ and $0.50 \%$, respectively) and straw $(0.45,0.10$ and $1.36 \%$, respectively) were noticed with $100 \%$ NPK over control. Significantly highest N, P and K uptake in grain to the tune of 80.30, 11.07 and $25.29 \mathrm{~kg} / \mathrm{ha}$, respectively, was recorded in treatment receiving $100 \% \mathrm{NPK}$, while the lowest in control $(22.19,2.70$ and $6.33 \mathrm{~kg} / \mathrm{ha}$, respectively). The same trend was also noticed in straw. Total $\mathrm{N}, \mathrm{P}$ and $\mathrm{K}$ uptake by wheat increased from 29.98 to $112.50,4.30$ to 18.22 and 34.94 to 121.21 $\mathrm{kg} / \mathrm{ha}$, respectively, with increase in the level of NPK from 0 to $100 \%$ (Tables 1 and 2). The uptake of N, P and $\mathrm{K}$ increased with progressive increase of NPK in the soil and higher availability of these nutrients to crop resulting in higher biomass yield (Chand 2008). This might be due to higher availability of nutrients and their efficient absorption by the roots of crop (White et al. 2013). The result of the present investigation corroborates with the findings of Singh and Singh (2012) and Jat et al. (2013). Data presented in Table 2 further showed that application of fertilizer at increasing levels significantly influenced the protein and carbohydrate content in grain 


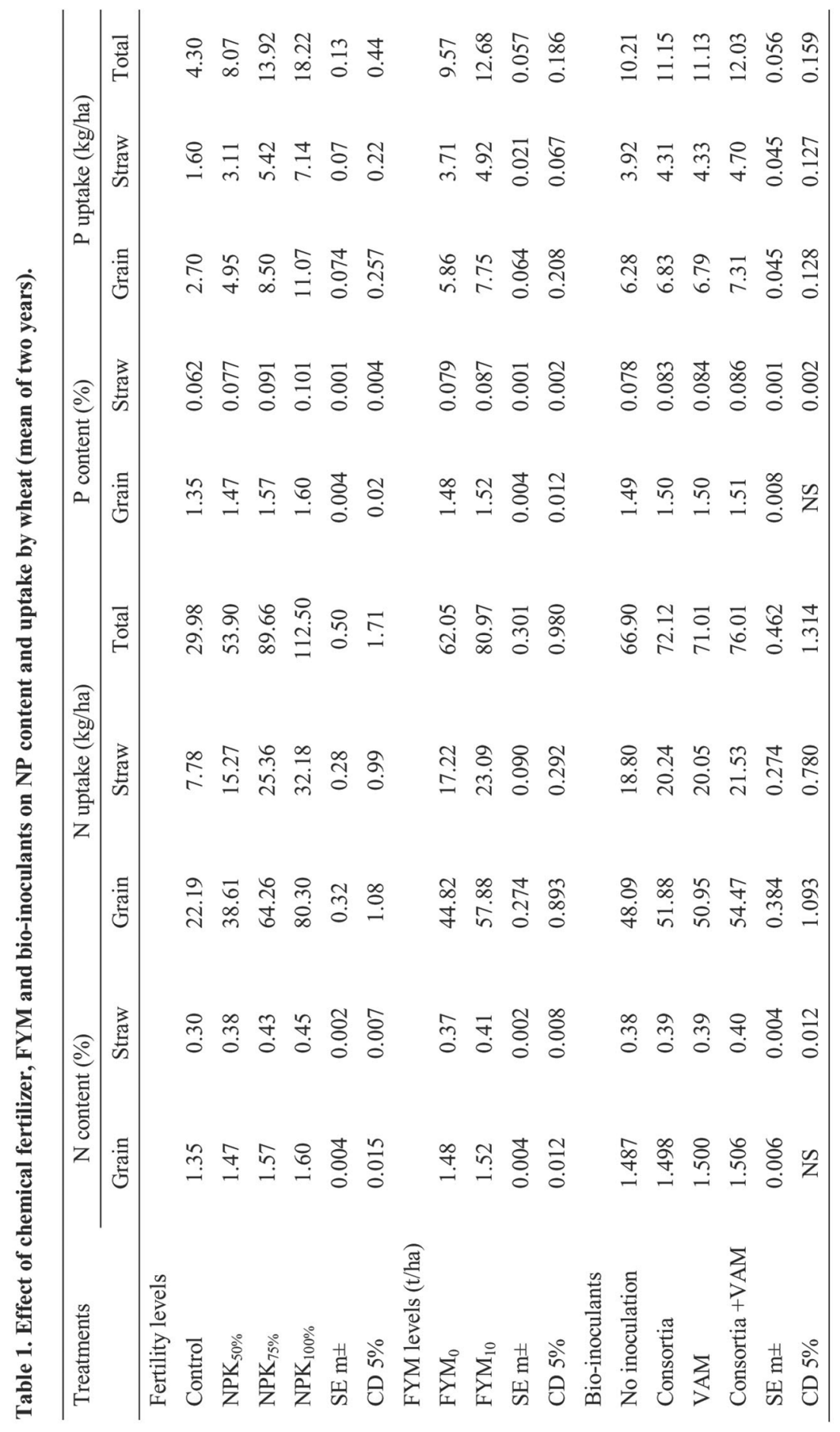


of wheat. On the basis of two year mean data, application of 50, 75 and 100\% NPK/ha resulted in 8.40, 14.11 and $18.55 \%$ increase in protein and $7.79,13.12$ and $17.22 \%$ in carbohydrate, respectively over control.

The similar trend of quality parameter increased with increasing levels of fertilizer application was also reported by Saha et al. (2010) and Sharma et al. (2013). Based on mean of the two-year data, an increase in grain yield amounting to $60.37,150.0$ and $206.1 \%$ was recorded with the application of 50\%, 75\% and $100 \%$ NPK/ha over control. Results of the present investigation are more or less similar with the findings of Dadhich et al. (2011).

An application of FYM @ 10 t/ha increased N, P and K content in grain (2.36, 2.70 and 6.0\%) and straw (11.38, 10.13 and 2.46\%), respectively, over no FYM. Application of FYM resulted in more uptakes of $\mathrm{N}, \mathrm{P}$ and $\mathrm{K}$ in grain and straw (Tables 1 and 2). Total uptake of $\mathrm{N}, \mathrm{P}$ and $\mathrm{K}$ increased by $18.92,3.11$ and $17.33 \mathrm{~kg} / \mathrm{ha}$, respectively, with FYM treatment over no FYM. Application of FYM not only increased the content and uptake of N, P and K through mineralization but also reduces the losses of $\mathrm{N}$ and hence enhances the availability of nutrients for longer period (Kumar and Singh 2013, Singh and Singh 2017).

Addition of FYM @ 10 t/ha significantly influenced the protein content in wheat grain. The protein content was increased by $3.22 \%$ over no FYM application. The significant increase in protein content in grain of wheat might be due to increased nitrogen content in grain and nitrogen which is an integral part of protein (Kumar and Singh 2013). The addition of FYM @ 10 t/ha gave significantly higher value of the carbohydrate content $(64.14 \%)$ over the treatment of without application of FYM. Among the FYM treatments, application of FYM @ 10 t/ha resulted significantly higher grain yield (3.74 t/ha), over without application of FYM treatment. The increase in yield of wheat might be due to slow decomposition of FYM and release of all essential nutrients throughout the crop growth resulting higher yield and better assimilation on nutrients (Kumar et al. 2015, Singh et al. 2016).

Results presented in Table 1 revealed that $\mathrm{N}$ and $\mathrm{P}$ content in straw of wheat increased with bio-inoculants over un-inoculated control. The maximum $\mathrm{N}$ and $\mathrm{P}$ content in straw was recorded with the treatment (Consortia + VAM) 0.40 and $0.086 \%$, respectively. Data presented in Tables 1 and 2 further showed that seed treatments with bio-inoculants have also significantly increased nutrient $(\mathrm{N}, \mathrm{P}$ and $\mathrm{K})$ uptake by grain and straw of wheat as compared to control. Among the bioinoculants, maximum nutrients (NPK) uptake was recorded in Consortia + VAM treatment followed by bio-inoculants. The use of composite cultures of Consortia + VAM significantly increased the total $\mathrm{N}(76.01 \mathrm{~kg} / \mathrm{ha}), \mathrm{P}(12.03 \mathrm{~kg} / \mathrm{ha})$ and $\mathrm{K}(81.56 \mathrm{~kg} / \mathrm{ha})$ uptake, which were significantly higher over control. Seed inoculation with different bio-inoculants slightly increased the protein content in grain as compared to control, but the levels of significance were not achieved. Maximum protein content in grain recorded in treatment Consortia + VAM (9.47\%). The slight improvement of protein content in grain might be due to the role of nitrogen fixing and other bio-inoculants on release of nutrients by mineralization of organic manure and production of endogenous phytohormones (IAA and GA) which played an important role in the formation of active root system, increasing the nutrients uptake and photosynthesis rate and translocation as well as accumulation of $\mathrm{N}$ within grain (Panwar and Singh 2000, Zaki et al. 2007). Bio-inoculants significantly increased grain yield of wheat. Results showed that grain yield of wheat significantly varied from 3.16 to 3.53 t/ha due to different bio-inoculants. The maximum values of grain yield, in the above ranges, were due to seed inoculation with Consortia + VAM, significantly higher over control as well as individual treatment of Consortia and VAM. This increment in yields might be due to the positive effect of inoculation on nutrients uptake and their assimilation processes in wheat plants which reflected an enhancing yield (Mahdi et al.2010). 


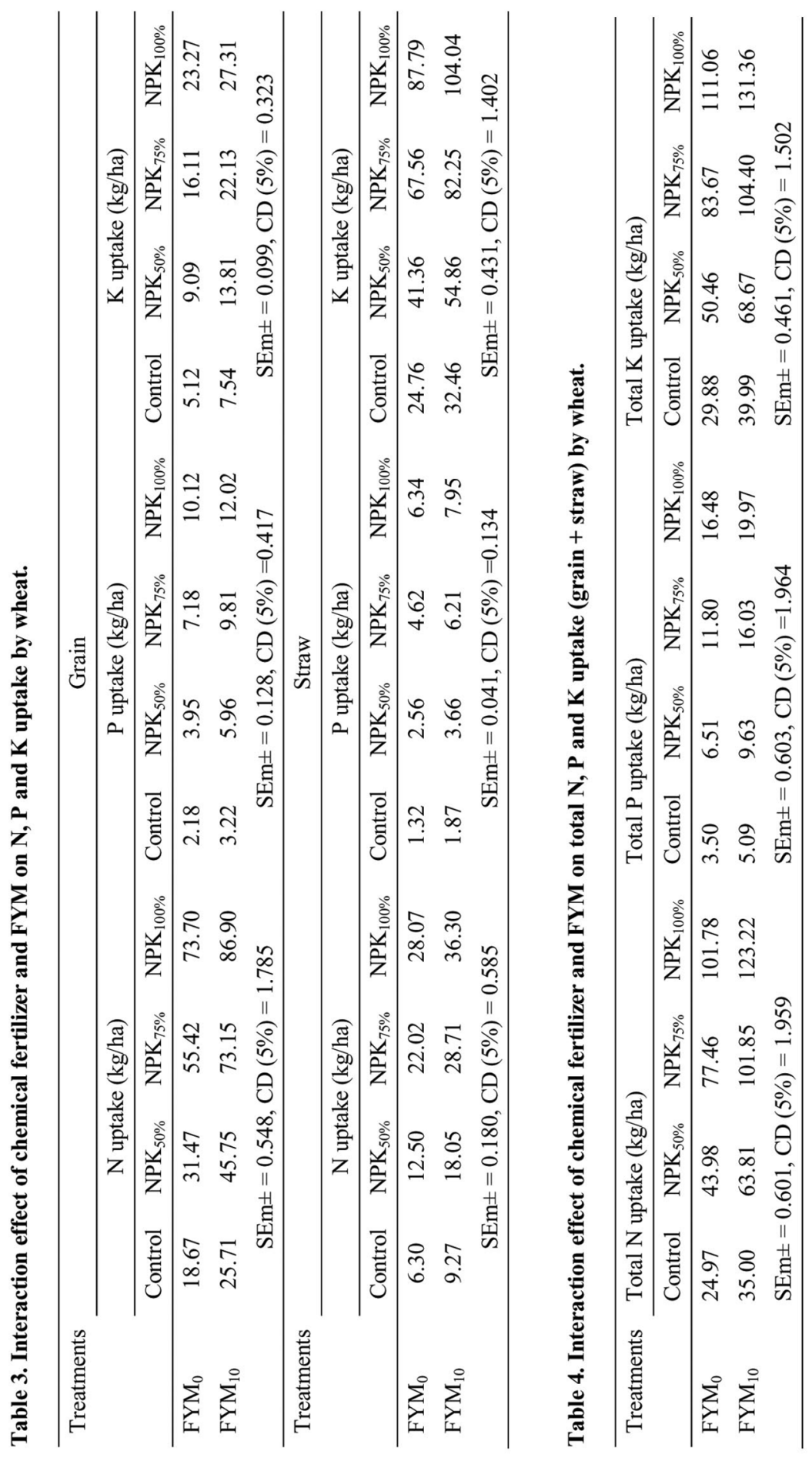




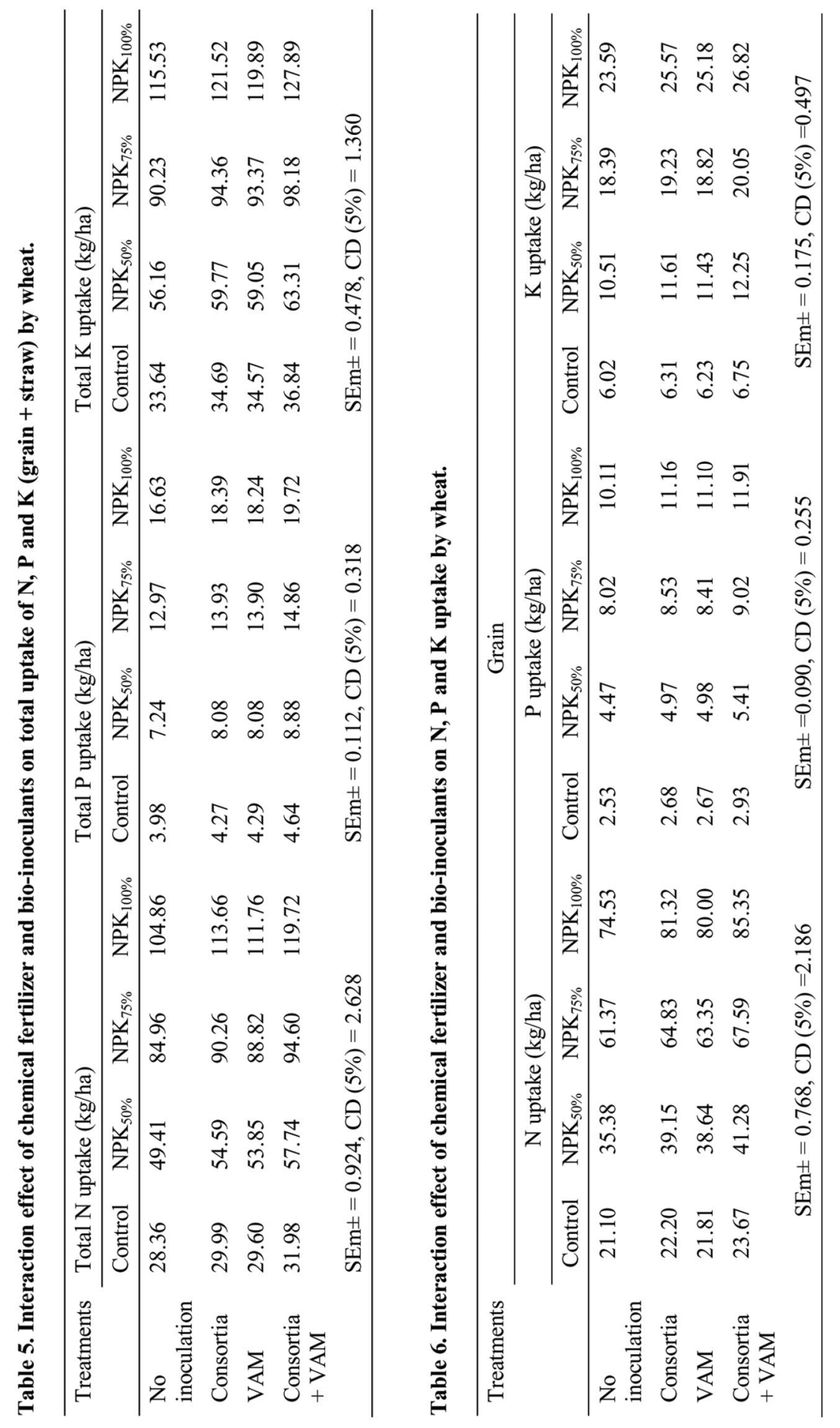


Data presented in Tables 3 and 4 showed that there was significant interaction between fertility levels and FYM on nutrient uptake by wheat. Application of $100 \%$ NPK with 10 t/ha FYM resulted in maximum nutrient uptake (Table 3). Moreover, the treatment receiving $75 \%$ NPK with 10 t/ha FYM resulted N and P uptake at par with that of $100 \%$ NPK. Data on the interactive effect of fertility levels and bioinoculants presented in Table 5 revealed that total nutrient uptake significantly increased with increasing levels of fertilizers in absence as well as in presence of bio-inoculants. The highest total N, P and K (119.72, 19.72 and $127.89 \mathrm{~kg} / \mathrm{ha}$, respectively), uptake was recorded with treatment involving application of $100 \%$ NPK fertilizer along with composite inoculation of Consortia + VAM followed by other treatment combinations. The positive interaction effect of fertility levels and bio-inoculants presented in Table 6 revealed that $\mathrm{N}, \mathrm{P}$, and $\mathrm{K}$ uptake significantly increased with increasing levels of fertilizers in absence as well as in presence of bio-inoculants. The highest N, P, and K uptake (85.35, 11.91 and 26.82 $\mathrm{kg} / \mathrm{ha}$, respectively) recorded with $100 \%$ NPK fertilizer along with composite inoculation of Consortia + VAM were significantly higher over control as well as over rest of the combinations. The results of the present investigation clearly indicated that in comparison to individual inoculants, combined inoculation of Consortia + VAM with all fertilizer levels could give significantly higher nutrient uptake.

Maximum increase in nutrient content, uptake, quality parameter and yield of wheat were recorded with $100 \%$ NPK, FYM and bio-inoculants and minimum at control. Combined use of fertilizer levels and FYM and fertilizer levels and bio-inoculants also showed significantly higher nutrient uptake by wheat. From the results it may be concluded that, application of $100 \%$ NPK along with FYM@10 t/ha and bio-inoculants in wheat greatly enhanced the nutrient content, uptake and quality parameters of wheat as compared to other combinations.

\section{References}

Chand TK 2008. Analysis of fertilizer use by crops. Indian J. Fert. 4: 11-16.

Dadhich SK, Somani LL and Shilpkar D 2011. Effect of integrated use of fertilizer P, FYM and biofertilizers on soil properties and productivity of soybean-wheat crop sequence. J. Adv. Develop. Res. 2(1):42-46.

Gomez KA and Gomez AA 1984. Statistical procedures for agricultural research, John Wiley and sons, Inc London, UK (2nd edtn) 13-175.

Jackson ML 1973. Soil Chemical Analysis, Prentice Hall, Pvt Ltd New Delhi. page 498.

Jat MK, Purohit HS, Singh B, Gaehwal RS and Choudhary M 2013. Effect of integrated nutrient management on yield and nutrient uptake in sorghum (Sorghum bicolor). Indian J. Agron. 58(4): 543-547.

Kumar D and Singh JP 2013. Integrated effect of copper and farmyard manure on yield, quality and uptake of nutrients in wheat. Ann. Plant Soil Res. 15(2): 156-159.

Kumar Y, Singh SP and Singh VP 2015. Effect of FYM and potassium on yield, nutrient uptake and economics of wheat in alluvial soil. Ann. Plant Soil Res. 17(1): 100-103.

Lowry OH, Rosebrough NJ, Farr AL and Randall RJ 1951. Protein measurement with the Folin phenol reagent. J. Biol. Chem. 193(1): 265-275.

Mahdi S, Hassan GI, Samoon SA, Rather HA and Showkat AD 2010. Biofertilizer in organic agriculture. J. Phyto. 2(10): 42-54.

MoA and FW. Ministry of Agriculture and Farmers Welfare, Government of India [Internet]. 2018. http://agricoop.gov.in/sites/default/files/agristatglance2018.pdf [Accessed: February 20, 2020].

Panwar JDS and Singh O 2002. Response of Azospirillum and Bacillus on growth yield of wheat under field conditions. Indian J. Plant Physio. 5: 108-110.

Parewa H P, Yadav J and Rakshit A 2014. Effect of Fertilizer Levels, FYM and Bioinoculants on Soil Properties in Inceptisol of Varanasi, Uttar Pradesh, India. Int. J. Agri. Environ. Biotechn. 7(3): 517-525. 
Rakshit A, Sarkar NC and Sen D 2008. Influence of organic manures on productivity of two varieties of rice. J. Central Euro. Agri. 9(4):629-634.

Saha S, Gopinath KA, Mina BL, Kundu S, Bhattacharyya R and Gupta HS 2010. Expression of soil chemical and biological behavior on nutritional quality of aromatic rice as influenced by organic and mineral fertilization. Commun. Soil Sci. Plant Analy. 41: 1816-1831.

Sharma GD, Thakur R, Som raj, Kauraw DL and Kulhare PS 2013. Impact of integrated nutrient management on yield, Nutrient uptake, protein content of wheat (Triticum astivam) and soil fertility in a typic haplustert, The Bioscan 8(4): 1159-1164.

Singh AP, Lal AK and Singh AP 2016. Effect of FYM, potassium and zinc on yield, quality and uptake of nutrients in forage oat in alluvial soil. Ann. Plant Soil Res. 18(4): 338-341.

Singh D, Chonker PK and Dwivedi BS 2005. Manual on soil, plant and water analysis Westville publication house, New Delhi, India. pp 200.

Singh DP and Singh D 2017. Effect of nitrogen and FYM on yield, quality and uptake of nutrients in wheat (Triticum aestivum). Ann. PlantSoil Res. 19(2): 232 - 236.

Singh S and Singh JP 2012. Effect of organic and inorganic nutrient sources on some soil properties and wheat yield. J. Indian Soc. Soil Sci. 60(3): 237-240.

Thimmaiah SR 1999. Standard methods of biochemical analysis, Kalyani publishers, New Delhi, 545.

White PJ, George TS, Dupuy LX, Karley AJ, Valentine TA, Wiesel L, et al. 2013. Root traits for infertile soils. Front. Plant Sci. 4:193. doi: 10.3389/fpls.2013.00193.

Zaki MN, Hassanein MS and Gamal El-Din M 2007. Growth and yield of some wheat cultivars irrigated with saline water in newly cultivated land as affected by biofertilization. J. Appl. Sci. Res. 3(10): 1121-1126.

(Manuscript received on 25 May, 2021; revised on 15 July, 2021) 